\title{
Anticancer activities of self-assembled molecular bowls containing a phenanthrene-based donor and $\mathrm{Ru}(\mathrm{II})$ acceptors
}

This article was published in the following Dove Press journal:

International Journal of Nanomedicine

25 August 2015

Number of times this article has been viewed

\author{
Inhye Kim ${ }^{1, *}$ \\ Young Ho Song 2 ,* \\ Nem Singh ${ }^{2}$ \\ Yong Joon Jeong ${ }^{3}$ \\ Jung Eun Kwon ${ }^{3}$ \\ Hyunuk Kim ${ }^{4}$ \\ Young $\mathrm{Mi} \mathrm{Cho}{ }^{3}$ \\ Se Chan Kang ${ }^{3}$ \\ $\mathrm{Ki}-$ Whan $\mathrm{Chi}^{2}$
}

'Laboratory of Bio-Resources, Yongin-si, Gyeonggi-Do, '2Department of Chemistry, University of Ulsan,

Ulsan, ${ }^{3}$ Department of Life Science, Gachon University, Seongnam, ${ }^{4}$ Energy Materials Lab, Korea Institute of Energy Research, Daejeon, Republic of Korea

*These authors contributed equally to this work
Correspondence: Ki-Whan Chi

Department of Chemistry, University of Ulsan, Ulsan 680-749, Republic of Korea Tel +82 522592344

Fax +82 522592348

Email kwchi@ulsan.ac.kr

Se Chan Kang

Department of Life Science,

Gachon University, Seongnam 46I-70I,

Republic of Korea

$\mathrm{Tel}+82317508826$

Fax +82 31 7508984

Email sckang73@gachon.ac.kr
Abstract: Nano-sized multinuclear ruthenium complexes have rapidly emerged as promising therapeutic candidates with unique anticancer activities. Here, we describe the coordinationdriven self-assembly and anticancer activities of a set of three organometallic tetranuclear $\mathrm{Ru}(\mathrm{II})$ molecular bowls. [2+2] Coordination-driven self-assembly of 3,6-bis(pyridin-3ylethynyl)phenanthrene (bpep) (1) and one of the three dinuclear arene ruthenium clips, $\left[\left(\eta^{6}-p \text {-iPrC }{ }_{6} \mathrm{H}_{4} \mathrm{Me}\right)_{2} \mathrm{Ru}_{2}-(\mathrm{OO} \backslash \mathrm{OO})\right][\mathrm{OTf}]_{2}(\mathrm{OO} \backslash \mathrm{OO}=2,5$-dioxido-1,4-benzoquinonato, OTf = triflate) (2), 5,8-dioxido-1,4-naphthoquinonato (3), or 6,11-dioxido-5,12-naphthacenediona (4), resulted in three molecular bowls 5-7 of general formula $\left[\left\{\left(\eta^{6}-p-\mathrm{PrC}_{6} \mathrm{H}_{4} \mathrm{Me}\right)_{2} \mathrm{Ru}_{2}-\right.\right.$ $\left.(\mathrm{OO} \backslash \mathrm{OO})\}_{2}(\text { bpep })_{2}\right][\mathrm{OTf}]_{4}$. All molecular bowls were obtained as triflate salts in very good yields $(>90 \%)$ and were fully characterized using multinuclear nuclear magnetic resonance (NMR), electrospray ionization-mass spectrometry (ESI-MS), and elemental analysis. The structure of the representative molecular bowl 5 was confirmed by single-crystal X-ray diffraction analysis. The anticancer activities of molecular bowls 5-7 were determined by 3-[4,5-dimethylthiazol2-yl]-2,5-diphenyltetrazolium bromide, autophagy, and Western blot analysis. Bowl 6 showed the strongest cytotoxicity in AGS human gastric carcinoma cells and was more cytotoxic than doxorubicin. In addition, autophagic activity and the ratio of apoptotic cell death increased in AGS cells by treatment with bowl $\mathbf{6}$. Bowl $\mathbf{6}$ also induced autophagosome formation via upregulation of p62 and promotion of the conversion of LC3-I to LC3-II. Moreover, bowl 6 promoted apoptotic cell death through downregulation of Akt/mTOR activation, followed by increased caspase- 3 activity. These results suggest that bowl $\mathbf{6}$ induces gastric cancer cell death via modulation of autophagy and apoptosis. Bowl 6 is a potent anticancer agent and a potential treatment for human gastric cancer that merits further study.

Keywords: phenanthrene, ruthenium, coordination self-assembly, gastric cancer, Akt/mTOR

\section{Introduction}

Research on nano-sized Ru(II)-based self-assembled architectures as anticancer compounds has increased rapidly following successful assessments of Ru-based small molecules as treatments for metastatic solid tumors in clinical trials. ${ }^{1-6}$ Thus, a growing number of Ru(II)-based, self-assembled large two-dimensional and three-dimensional architectures have been developed which have shown promising results in human cancer cell lines as antitumor agents. ${ }^{7-14}$ Therrien and others exploited the self-assembly approach to design finite, nano-sized molecular architectures by combining organometallic halfsandwich acceptor clips and pyridyl-based donors. ${ }^{15-18}$ Nanostructures based on halfsandwich arene-ruthenium complexes are promising candidates for cancer treatments, as they possess advantageous features such as low toxicity and a balance of hydrophilicity 
and hydrophobicity, a key issue for their transport in biological media. ${ }^{19}$ Phenanthrene-derived synthetic and natural products have demonstrated a variety of pharmacological effects, such as cytotoxicity, phytotoxicity, and anti-inflammatory, antimicrobial, antioxidant, antiplatelet aggregation, and antiallergic activities. ${ }^{20-24}$ These important findings laid the foundation for the design of new nano-sized self-assembled architectures with phenanthrene-derived donors and arene- $\mathrm{Ru}-$ based acceptors, with the expectation of improved biological results in comparison with available chemotherapeutic agents. Studies on similar complexes suggest that phenanthrene-derived donors and arene- $\mathrm{Ru}$-based acceptors will work together in a synergistic manner as complementary building blocks; the phenanthrene unit will interact with DNA, whereas the ruthenium center will bind to proteins. ${ }^{6}$ Anthracene, ${ }^{17}$ naphthelenediimide, ${ }^{11}$ carbazole ${ }^{8}$ and many other dipyridyl donors have been used in the self-assembly of various molecular architectures ${ }^{9}$ that have shown promising anticancer activities; however, Ru-based architectures generated with phenanthrene derivatives have not been explored.

The three primary types of programmed cell death (PCD) are apoptosis (the predominant type of PCD, type I PCD), autophagy (type II PCD), and necroptosis (type III PCD), which can be distinguished according to cellular and nuclear morphology. Chemotherapeutic agents can produce anticancer effects by modulating autophagy and apoptosis. Apoptosis is related to the activation of caspases and a stereotypical sequence of mitochondrial alterations..$^{25,26}$ In recent years, apoptosis induction has been prioritized as a target mechanism of action for cancer treatment agents in development. However, chemo-resistance in cancer cells inhibits the proapoptotic effects of chemotherapeutic agents. Therefore, induction of autophagic cell death is considered to be another potential target mechanism that could be exploited to suppress tumor growth and alleviate treatment resistance in apoptosisdefective tumor cells. ${ }^{27}$ Autophagy is an evolutionarily catabolic process that plays a vital role in cellular degradation and cell survival. ${ }^{27}$ Although autophagy is normally maintained at a low basal level, dysregulated autophagy is observed in cancer pathology, inflammatory diseases, metabolic diseases, and neurodegenerative diseases. ${ }^{28-31}$ Recently, autophagy has been noted as a target for anticancer drugs that suppress tumorigenesis. ${ }^{32,33}$ Additionally, a number of studies have suggested that autophagy is closely connected with apoptosis, as highlighted by the finding that the induction of apoptosis is often related to increased autophagy. ${ }^{34,35}$ Therefore, accumulating studies indicate that autophagy-modulating agents may provide a new wave of therapeutic drugs and strategies for cancer treatment.
Herein, we present a set of three tetranuclear $\mathrm{Ru}(\mathrm{II})$ metalla-bowls 5-7 incorporating a new phenanthrene-derived donor 1 and dinuclear Ru(II) $p$-cymene acceptors 2-4. All three molecular bowls were evaluated for their cytotoxicity against human tumor cell lines. Bowl $\mathbf{6}$ was found to show remarkable selectivity for the AGS human gastric carcinoma cell line. Furthermore, we found that bowl $\mathbf{6}$ induced autophagy and apoptosis by inducing conversion of LC3-I to LC3-II and inhibiting the Akt/mTOR signaling pathway.

\section{Materials and methods}

All chemicals used in this work were purchased from commercial sources and used without further purification. All solvents were distilled by standard methods prior to use. The starting arene-ruthenium acceptor clips ${ }^{10,36}$ and 3,6-dibromophenanthrene ${ }^{37}$ were prepared as previously described. The ${ }^{1} \mathrm{H}$ and ${ }^{13} \mathrm{C}$ NMR spectra were recorded with a Bruker $300 \mathrm{MHz}$ spectrometer. Mass spectra for the selfassembled architectures were recorded using electrospray ionization with a MassLynx operating system at the Korea Basic Science Institute (Seoul, Korea). Elemental analyses were performed at the Technical Support Centre, Pohang University of Science and Technology.

\section{Crystallographic data collection and structure refinement}

The diffraction data from single crystals mounted on a loop were collected at $100 \mathrm{~K}$ on an ADSC Quantum $210 \mathrm{CCD}$ diffractometer with synchrotron radiation $(\lambda=0.80000 \AA)$ at Macromolecular Crystallography Beamline 2D, Pohang Accelerator Laboratory, Pohang, Korea. The raw data were processed and scaled using the HKL2,000 program. The structure was solved by direct methods, and the refinements were carried out with full-matrix least squares on F2 with appropriate software implemented in the SHELXTL program package. X-ray data for complex 5: $\mathrm{C}_{113} \mathrm{H}_{96} \mathrm{~F}_{12} \mathrm{~N}_{4} \mathrm{O}_{21} \mathrm{Ru}_{4} \mathrm{~S}_{4}, \mathrm{M}=2,606.46$, triclinic, $P \overline{1}, \mathrm{a}=16.457(3) \AA, \mathrm{b}=18.067(4) \AA, \mathrm{c}=22.099(4) \AA$, $\alpha=68.36(3)^{\circ}, \beta=81.25(3)^{\circ}, \gamma=64.86(3)^{\circ}, V=5,527.2(19) \AA^{3}$, $\mathrm{Z}=2, \mathrm{~T}=100 \mathrm{~K}, \mu$ (synchrotron $)=0.504 \mathrm{~mm}^{-1}, \rho_{\text {calcd }}=1.566 \mathrm{~g}$ $\mathrm{cm}^{-3}, 26,273$ reflections measured, $\mathrm{R} 1=0.0670$ and $\mathrm{wR} 2$ $=0.2255$ for 26,273 reflections $(\mathrm{I}>2 \sigma(\mathrm{I})), \mathrm{R} 1=0.1163$ and $\mathrm{wR} 2=0.2834$ (all data), GoF $=1.233,1,498$ parameters, and 195 restraints, CCDC:1062887. All of the non-hydrogen atoms were refined anisotropically. Hydrogen atoms were added to their geometrically ideal positions.

\section{Synthesis of dipyridyl phenanthrene donor I}

To a round-bottom flask, 3,6-dibromophenanthrene (89.6 mg, $0.267 \mathrm{mmol}), 3$-ethynylpyridine $(63.3 \mathrm{mg}$, 
$0.613 \mathrm{mmol}), \mathrm{CuI}(2.5 \mathrm{mg}, 0.013 \mathrm{mmol}),\left[\mathrm{PdCl}_{2}\left(\mathrm{PPh}_{3}\right)_{2}\right]$ (11.2 mg, $0.016 \mathrm{mmol}$ ), and $\mathrm{PPh}_{3}(4.2 \mathrm{mg}, 0.016 \mathrm{mmol})$ were added. THF $(5 \mathrm{~mL})$ and triethylamine $(5 \mathrm{~mL})$ were added to the flask and bubbled with $\mathrm{N}_{2}$ for 10 minutes. The resulting reaction mixture was refluxed under nitrogen for 2 days and cooled, after which the solvent was removed under vacuum. The resulting residue was purified by flash column chromatography $\left(\mathrm{SiO}_{2}\right.$, ethyl acetate with $2 \%$ triethylamine) to afford 1 as a white solid. Yield: $48 \%$. Mp: $221^{\circ} \mathrm{C}-223^{\circ} \mathrm{C}$. Anal calcd for $\mathrm{C}_{28} \mathrm{H}_{16} \mathrm{~N}_{2}: \mathrm{C}, 88.40 ; \mathrm{H}, 4.24 ; \mathrm{N}$, 7.36. Found: C, 88.12; H, 4.22; N, 7.40. ${ }^{1} \mathrm{H}$ NMR (300 MHz, $\left.\mathrm{CD}_{3} \mathrm{NO}_{2} / \mathrm{CD}_{3} \mathrm{OD}\right) \delta 9.03(\mathrm{~d}, J=1.5 \mathrm{~Hz}, 1 \mathrm{H}), 8.82$ (dd, $J=1.8$, $0.9 \mathrm{~Hz}, 1 \mathrm{H}), 8.56$ (dd, $J=4.8,1.8 \mathrm{~Hz}, 1 \mathrm{H}), 8.07$ (dd, $J=7.9$, $1.8 \mathrm{~Hz}, 1 \mathrm{H}), 8.01(\mathrm{~d}, J=8.3 \mathrm{~Hz}, 1 \mathrm{H}), 7.88(\mathrm{~s}, 1 \mathrm{H}), 7.82(\mathrm{dd}$, $J=8.3,1.5 \mathrm{~Hz}, 1 \mathrm{H}), 7.51(\mathrm{ddd}, J=7.9,4.8,0.9 \mathrm{~Hz}, 1 \mathrm{H}) .{ }^{13} \mathrm{C}$ NMR (75 MHz, $\left.\mathrm{CDCl}_{3}\right) \delta 152.17,148.53,138.99,132.33$, $129.82,129.69,129.04,127.83,126.74,123.45,121.04$, 120.75, 93.57, 86.91. HRMS for $\mathrm{C}_{28} \mathrm{H}_{16} \mathrm{~N}_{2}$ : calcd, 380.1313; observed, 380.1314 .

\section{General procedure for the self-assembly of molecular bowls 5-7}

Phenanthrene donor $\mathbf{1}$ and an arene-Ru(II) acceptor $\mathbf{2}$, 3 , or 4 were stirred in $1.5 \mathrm{~mL}$ nitromethane/methanol (1:1) at room temperature for 6 hours to obtain a clear solution, to which diethyl ether was added dropwise to precipitate the product, which was washed twice with diethyl ether via centrifugation. The resulting crystalline powders were dried to obtain pure samples of the molecular bowls.

\section{Molecular bowl 5}

Molecular bowl 5 was self-assembled by the general procedure described using phenanthrene donor 1 (1.14 mg, $0.003 \mathrm{mmol}$ ) and acceptor $2(2.72 \mathrm{mg}, 0.003 \mathrm{mmol})$. The dark-red colored crystalline powder was characterized as 5 (3.55 mg, yield: 92\%). Mp: $233^{\circ} \mathrm{C}-235^{\circ} \mathrm{C}$ (dec.). Anal. calcd for $\mathrm{C}_{112} \mathrm{H}_{92} \mathrm{~F}_{12} \mathrm{~N}_{4} \mathrm{O}_{20} \mathrm{Ru}_{4} \mathrm{~S}_{4}: \mathrm{C}, 52.25 ; \mathrm{H}, 3.60 ; \mathrm{N}, 2.18$. Found: C, 52.39; H, 3.59; N, 2.17. ${ }^{1} \mathrm{H}$ NMR (300 MHz, $\left.\mathrm{CD}_{3} \mathrm{NO}_{2} / \mathrm{CD}_{3} \mathrm{OD}\right) \delta 8.41(\mathrm{~s}, 2 \mathrm{H}), 8.37(\mathrm{~s}, 2 \mathrm{H}), 8.24$ (d, $J=7.1 \mathrm{~Hz}, 2 \mathrm{H}), 8.03(\mathrm{~d}, J=5.7 \mathrm{~Hz}, 2 \mathrm{H}), 7.53-7.36$ (m, 8H), 6.07 (d, $J=6.3 \mathrm{~Hz}, 4 \mathrm{H}), 5.84$ (d, J=6.3 Hz, 6H), 2.91 (d, J=6.9 Hz, 2H), 2.22 (s, 6H), 1.35 (d, $J=6.9 \mathrm{~Hz}, 12 \mathrm{H})$. ${ }^{13} \mathrm{C}$ NMR (75 MHz, $\left.\mathrm{CD}_{3} \mathrm{NO}_{2} / \mathrm{CD}_{3} \mathrm{OD}\right) \delta 184.77,155.68$, $152.58,142.90,133.28,130.20,129.95,129.68,128.69$, $127.05,124.31,124.03,120.62,119.80,105.49,102.82$, 100.41, 97.07, 84.69, 84.65, 82.76, 32.54, 22.46, 18.29. ESI-MS for $\mathrm{C}_{109} \mathrm{H}_{92} \mathrm{~F}_{3} \mathrm{~N}_{4} \mathrm{O}_{11} \mathrm{Ru}_{4} \mathrm{~S}$ : calcd, 709.42 [5-3OTf] ${ }^{+3}$; observed, 709.32 .

\section{Molecular bowl 6}

Molecular bowl 6 was self-assembled by the general procedure described using phenanthrene donor $\mathbf{1}(1.14 \mathrm{mg}$, $0.003 \mathrm{mmol}$ ) and acceptor $3(2.87 \mathrm{mg}, 0.003 \mathrm{mmol})$. The greenish colored crystalline powder was characterized as $\mathbf{6}$. Isolated yield: $90 \%$. Mp: $238^{\circ} \mathrm{C}-239^{\circ} \mathrm{C}$ (dec.). Anal. calcd for $\mathrm{C}_{120} \mathrm{H}_{96} \mathrm{~F}_{12} \mathrm{~N}_{4} \mathrm{O}_{20} \mathrm{Ru}_{4} \mathrm{~S}_{4}$ : C, 53.89; H, 3.62; N, 2.09. Found: C, $53.81 ; \mathrm{H}, 3.63 ; \mathrm{N}, 2.10 .{ }^{1} \mathrm{HNMR}\left(300 \mathrm{MHz}, \mathrm{CD}_{3} \mathrm{NO}_{2} / \mathrm{CD}_{3} \mathrm{OD}\right)$ $\delta 8.50(\mathrm{~d}, J=1.7 \mathrm{~Hz}, 2 \mathrm{H}), 8.38(\mathrm{~s}, 2 \mathrm{H}), 8.20(\mathrm{~d}, J=4.7 \mathrm{~Hz}, 2 \mathrm{H})$, $8.16(\mathrm{~d}, J=7.9 \mathrm{~Hz}, 2 \mathrm{H}), 7.51$ (d, J=8.2 Hz, 2H), 7.44-7.32 $(\mathrm{m}, 6 \mathrm{H}), 7.26(\mathrm{~s}, 4 \mathrm{H}), 5.84(\mathrm{~d}, J=6.3 \mathrm{~Hz}, 4 \mathrm{H}), 5.59$ (d, $J=6.3 \mathrm{~Hz}, 4 \mathrm{H}), 2.89$ (d, $J=6.9 \mathrm{~Hz}, 2 \mathrm{H}), 2.14$ (s, 6H), 1.34 (d, $J=6.9 \mathrm{~Hz}, 12 \mathrm{H}) .{ }^{13} \mathrm{C} \mathrm{NMR}\left(75 \mathrm{MHz}, \mathrm{CD}_{3} \mathrm{NO}_{2} / \mathrm{CD}_{3} \mathrm{OD}\right)$ $\delta 171.91,154.93,151.80,142.60,138.66,133.19,130.32$, $129.86,129.72,128.60,127.03,126.44,123.83,120.72$, $119.81,112.59,104.81,101.26,96.42,85.65,85.00,83.73$, 31.94, 22.40, 17.43. ESI-MS for $\mathrm{C}_{117} \mathrm{H}_{96} \mathrm{~F}_{3} \mathrm{~N}_{4} \mathrm{O}_{11} \mathrm{Ru}_{4} \mathrm{~S}$ : calcd,

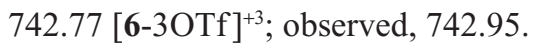

\section{Molecular bowl 7}

Molecular bowl 7 was self-assembled by the general procedure described using phenanthrene donor $\mathbf{1}$ (1.14 mg, $0.003 \mathrm{mmol}$ ) and acceptor 4 (3.17 $\mathrm{mg}, 0.003 \mathrm{mmol})$. The dark-green colored crystalline powder was characterized as 7. Isolated yield: $94 \%$. Mp: $240^{\circ} \mathrm{C}-241^{\circ} \mathrm{C}$ (dec.). Anal. calcd. for $\mathrm{C}_{136} \mathrm{H}_{104} \mathrm{~F}_{12} \mathrm{~N}_{4} \mathrm{O}_{20} \mathrm{Ru}_{4} \mathrm{~S}_{4}: \mathrm{C}, 56.82 ; \mathrm{H}, 3.65 ; \mathrm{N}, 1.95$. Found: C, 56.89; H, 3.64; N, 1.96. ${ }^{1} \mathrm{H}$ NMR (300 MHz, $\mathrm{CD}_{3} \mathrm{NO}_{2} /$ CD 3 OD) $\delta 8.74(\mathrm{dd}, J=5.8,3.3 \mathrm{~Hz}, 4 \mathrm{H}), 8.60(\mathrm{~s}, 2 \mathrm{H}), 8.21$ (d, $J=5.6 \mathrm{~Hz}, 2 \mathrm{H}), 8.16(\mathrm{~s}, 2 \mathrm{H}), 8.06(\mathrm{dd}, J=5.8,3.3 \mathrm{~Hz}, 4 \mathrm{H})$, 7.98 (d, J=8.1 Hz, 2H), 7.44 (d, J=8.2 Hz, 2H), 7.34 (s, 2H), 7.19 (dd, $J=8.1,5.7 \mathrm{~Hz}, 2 \mathrm{H}), 7.11$ (d, J=8.2 Hz, 2H), 6.04 (d, $J=6.3 \mathrm{~Hz}, 4 \mathrm{H}), 5.75$ (d, $J=6.3 \mathrm{~Hz}, 4 \mathrm{H}), 3.05$ (dt, $J=13.9$, $6.9 \mathrm{~Hz}, 2 \mathrm{H}), 2.26$ (s, 6H), 1.39 (d, J=6.9 Hz, 12H). ${ }^{13} \mathrm{C}$ $\mathrm{NMR}\left(75 \mathrm{MHz}, \mathrm{CD}_{3} \mathrm{NO}_{2} / \mathrm{CD}_{3} \mathrm{OD}\right) \delta 170.33,155.58,151.69$, $141.96,134.87,134.26,133.06,130.03,129.82,129.43$, $128.54,128.32,126.83,126.35,123.52,120.53,119.80$, $108.27,104.42,101.34,96.15,85.75,84.80,83.11,32.07$, 22.56, 17.92. ESI-MS for $\mathrm{C}_{133} \mathrm{H}_{104} \mathrm{~F}_{3} \mathrm{~N}_{4} \mathrm{O}_{11} \mathrm{Ru}_{4} \mathrm{~S}$ : calcd $809 .{ }^{44}$ [7-3OTf $]^{+3}$; observed, 809.49.

\section{Cell culture and reagents}

HCT-15 human colorectal cancer cells, SK-hep-1 human liver cancer cells, AGS human gastric cancer cells, and COS-7 monkey fibroblasts were obtained from the American Type Culture Collection (ATCC, Manassas, VA, USA). The HCT-15, AGS, and COS-7 cells were cultured in Dulbecco's Modified Eagle's Medium. The SK-hep-1 cells were cultured in RPMI 1640 medium. The cells were supplemented with $5 \%$ fetal bovine serum and $1 \%$ penicillin/streptomycin 
and incubated at $37^{\circ} \mathrm{C}$ in a humidified atmosphere of $5 \%$ $\mathrm{CO}_{2}$. The human cell lines used in this experiment were handled in accordance with the guidelines for human cell line experiment. This study was approved by the Ethics Committee of Gachon University Institutional Animal Care and Use.

\section{Cell viability assay}

The cells $\left(5 \times 10^{3}\right.$ cells per well) were seeded into 96-well plates and incubated at $37^{\circ} \mathrm{C}$ overnight, followed by stimulation with each compound dissolved in dimethyl sulfoxide (DMSO) for the indicated periods of time. After incubation, the cells were cultured with $10 \mu \mathrm{L}$ of 3-[4,5-dimethylthiazol2-yl]-2,5-diphenyltetrazolium bromide solution for 4 hours at $37^{\circ} \mathrm{C}$ in a humidified atmosphere of $5 \% \mathrm{CO}_{2}$. The formazan formed during the culture period was dissolved in $100 \mu \mathrm{L}$ of DMSO. The absorbance of the resulting solution was measured at $550 \mathrm{~nm}$ using a microplate reader. The half-maximal inhibitory concentration $\left(\mathrm{IC}_{50}\right)$ values for cell growth were calculated by fitting the plot of the logarithmic percentage of surviving cells against the logarithm of the drug concentration using a linear regression function.

\section{Labeling of autophagic vacuoles with monodansylcadaverine}

The autophagic activity of bowls 5-7 was determined by fluorescent monodansylcadaverine (MDC) staining. Cells were labeled with 0.05 mM MDC (Sigma-Aldrich, St Louis, MO, USA) in RPMI 1640 medium at $37^{\circ} \mathrm{C}$ for 10 minutes, after which they were washed three times with phosphate buffered saline (PBS) and immediately observed under a fluorescence microscope (Nikon Eclipse TE 300, Tokyo, Japan) equipped with a filter system (V-2A excitation filter, $380 / 420 \mathrm{~nm}$; barrier filter, $450 \mathrm{~nm}$ ).

\section{Tali ${ }^{\circledR}$ image-based cytometric assay}

Apoptosis was assessed using the $\mathrm{Tali}^{\circledR}$ Image-Based Cytometer (Thermo Fisher Scientific, Waltham, MA, USA) as described previously. ${ }^{38,39}$ Briefly, the AGS and COS-7 cells were treated with bowl 6 at concentrations from $0 \mu \mathrm{M}$ to $20 \mu \mathrm{M}$ for 24 hours at $37^{\circ} \mathrm{C}$ in an atmosphere of $5 \% \mathrm{CO}_{2}$. The number of cells was measured using a Countess ${ }^{\circledR}$ Automated Cell Counter. The cells were harvested using TrypLE ${ }^{\text {TM }}$ reagent and stained with the Tali ${ }^{\circledR}$ Apoptosis Kit. For the estimation of apoptotic cell death, the cells were stained with the annexin V-Alexa Fluor ${ }^{\circledR} 488$ conjugate. Propidium iodide (PI) was used to differentiate the cells that were necrotic (annexin $\mathrm{V}$ positive/PI positive or annexin $\mathrm{V}$ negative/PI positive) from those that were apoptotic (annexin $\mathrm{V}$ positive/PI negative). The percentages of the population reported as viable, apoptosis, and necrosis by the Tali ${ }^{\circledR}$ cytometer were comparable with data obtained when the same samples were run independently on a flow cytometer.

\section{Western blot analysis}

Cultured cells were washed with cold PBS and lysed with RIPA lysis buffer (Santa Cruz Biotechnology, Inc., Dallas, TX, USA) to allow protein extraction. The protein concentration was determined using a commercial protein assay kit (Bio-Rad Laboratories Inc., Hercules, CA, USA). Bovine serum albumin was used for the standard curve. Equal amounts of each total protein lysate $(20 \mu \mathrm{g})$ were resolved by $10 \%$ sodium dodecyl sulfate-polyacrylamide gel electrophoresis and transferred onto Immobilon ${ }^{\circledR}$-P polyvinylidene difluoride membranes (Amersham, Arlington Heights, IL, USA), which were incubated overnight with primary antibodies. The membranes were subsequently probed with horseradish peroxidase-conjugated secondary antibodies and visualized using an enhanced chemiluminescence kit (Amersham).

\section{Caspase- 3 activity analysis}

AGS cells were seeded into 96-well clear-bottom plates. Caspase-3 activity was measured using the Caspase-Glo_3 Assay kit (CG3 kit; Promega Corporation, Fitchburg, WI, USA) according to the manufacturer's protocol. The CG3 Assay is based on the cleavage of the specific sequence of a luminogenic substrate by caspase-3, which results in a luminescent signal. Fluorescence was measured at an excitation wavelength of $485 \mathrm{~nm}$ and an emission wavelength of $527 \mathrm{~nm}$ using a Mikrowin 2,000 Plate Reader (Tecan, Männedorf, Switzerland).

\section{Statistical analysis}

Data are presented as mean \pm standard error of mean Statistical analysis was determined by one-way analysis of variance using Sigma STAT (Jandel Software, San Raphael, CA, USA). Differences between individual groups were assessed using Dunnett's test. Statistical significance was considered as $P<0.05$ and $P<0.01$.

\section{Results and discussion Synthesis and characterization of molecular bowls 5-7}

Phenanthrene-derived donor 1 was prepared by Sonagashira coupling of 3,6-dibromophenathrene and fully characterized by multinuclear NMR and high-resolution mass spectroscopy (Figure 1). 


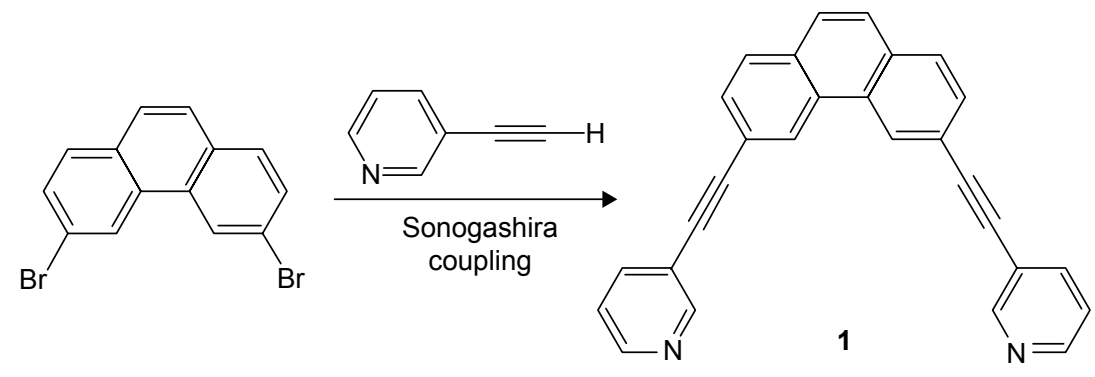

Figure I Synthesis of phenanthrene donor I.

The pure dipyridyl donor $\mathbf{1}$ was mixed separately with dinuclear $\mathrm{Ru}(\mathrm{II}) p$-cymene acceptors $\mathbf{2}-\mathbf{4}$ and solvent $\mathrm{CH}_{3} \mathrm{NO}_{2} / \mathrm{CH}_{3} \mathrm{OH}(1 / 1)$ was added to each resulting mixture. The reaction mixtures were stirred at room temperature for 6 hours to obtain clear solutions. Precipitation and filtration via the addition of diethyl ether yielded $\mathbf{5 - 7}$ as analytically pure crystalline powders (Figure 2). The new molecular bowls 5-7 were fully characterized by ${ }^{1} \mathrm{H}$ and ${ }^{13} \mathrm{C}$ NMR, ESI-MS, and elemental analysis. The solid-state structure of complex 5 was determined by single-crystal X-ray analysis.

The ${ }^{1} \mathrm{H}$ NMR spectra in $\mathrm{CD}_{3} \mathrm{OD} / \mathrm{CD}_{3} \mathrm{NO}_{2}$ (1/1) clearly indicated the formation of molecular bowls 5-7 with typical resonance shifts relative to those of the free donor and acceptors due to metal-ligand binding. ${ }^{9}$ The $\alpha$-pyridyl protons of donor 1 shifted upfield by $0.4-0.6 \mathrm{ppm}$ on complexation with acceptors 2-4. The ${ }^{1} \mathrm{H}$ NMR peaks associated with the phenanthrene unit also significantly shifted upfield. ESI-MS analysis confirmed the formation of molecular bowls 5-7. The isotopic distribution peaks for molecular bowls $\mathbf{5 , 6}$, and $\mathbf{7}$ observed at $\mathrm{m} / \mathrm{z}$ 709.32, 742.96 , and 809.49, respectively, corresponded to [M-3OTf] ${ }^{3+}$ and were in good agreement with the theoretical isotopic distribution patterns for these compounds (Figure 3)
The molecular structure of bowl $\mathbf{5}$ was unambiguously confirmed by single-crystal X-ray analysis (Figure 4). A suitable single crystal of $\mathbf{5}$ for X-ray crystallography using synchrotron radiation was obtained by slow vapor diffusion of diethyl ether into a concentrated $\mathrm{CH}_{3} \mathrm{NO}_{2} / \mathrm{CH}_{3} \mathrm{OH}$ (1:1) solution containing 5. X-ray analysis revealed that the two phenanthrene units were closely stacked with strong $\pi-\pi$ interactions at the interplanar distance of $\sim 3.5 \AA$. The strong $\pi-\pi$ interactions between phenanthrene units forced the molecule into a bowl-like shape. The maximum interatomic distance of the structure was found to be $1.975 \mathrm{~nm}$ between $\mathrm{C} 107$ and $\mathrm{C} 106$. The average $\mathrm{Ru}-\mathrm{N}$ pyridine bond distances were $2.11 \AA$, which was comparable to that of other tetranuclear architectures. ${ }^{9}$ Two views of the structure of $\mathbf{5}$ are shown in Figure 4.

\section{Cytotoxicity of organometallic multinuclear bowls 5-7 against human cancer cell lines}

We first assessed the cytotoxic potential of each organometallic multinuclear arene-Ru(II) complex by determining

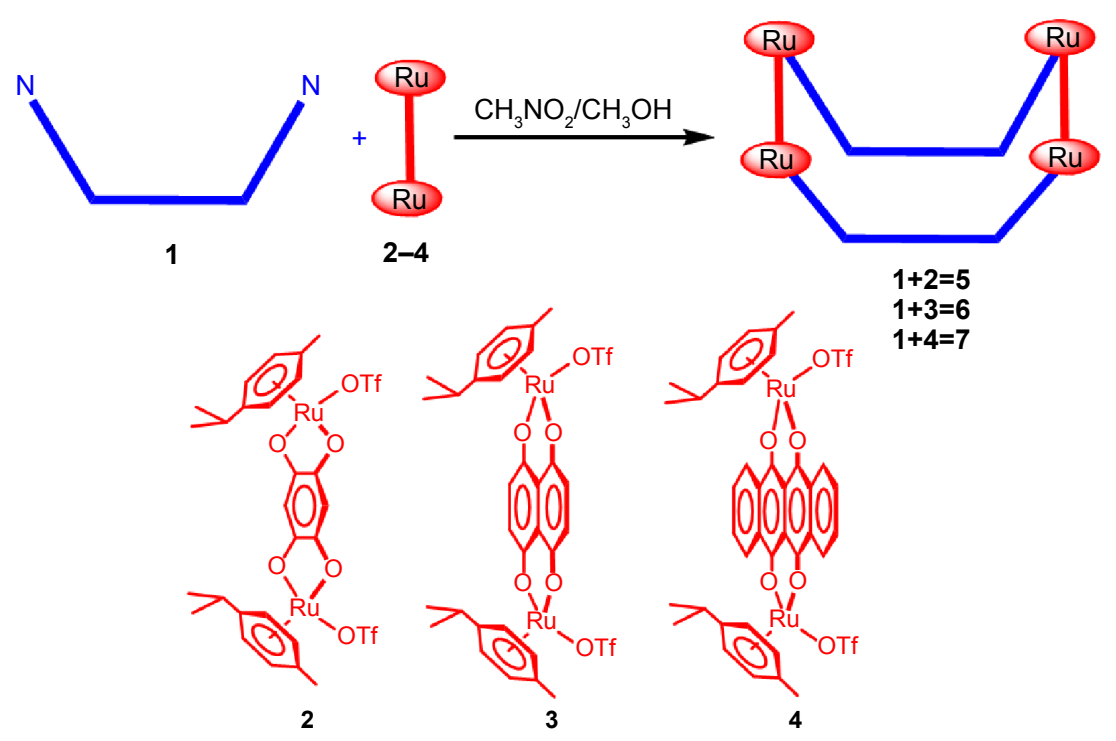

Figure 2 Self-assembly of molecular bowls 5-7.

Notes: Molecular bowl $\mathbf{5}$ was self-assembled using I and 2. Molecular bowl $\mathbf{6}$ was self-assembled using I and 3. Molecular bowl 7 was self-assembled using I and 4 . 

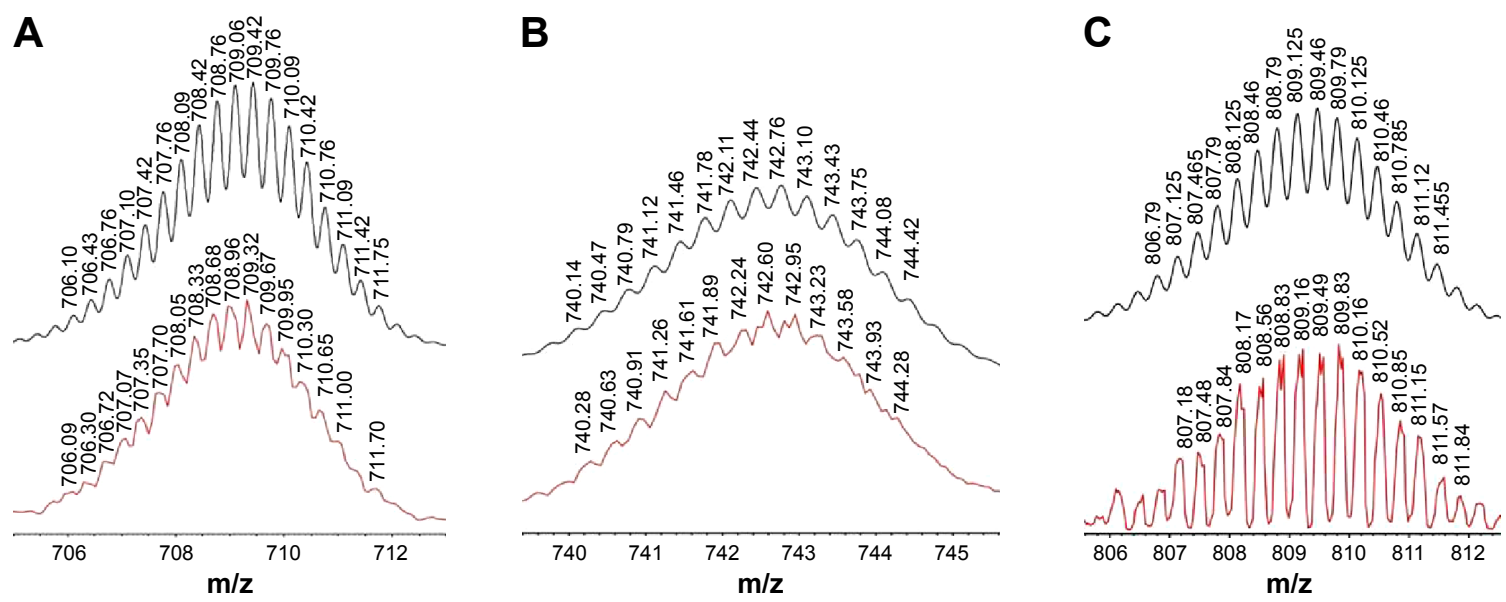

Figure 3 Electrospray ionization-mass spectrometry spectra of molecular bowls $(\mathbf{A})[\text { [5-3OTf }]^{3+},(\mathbf{B})[6-30 T f]^{3+}$, and $(\mathbf{C})[\text { 7-3OTf }]^{3+}$.

their $\mathrm{IC}_{50}$ values in three types of human cancer cells. For these experiments, the effects of the compounds were assessed in HCT-15, SK-hep-1, and AGS cells, which were derived separately from colon cancer, hepatic cancer, and gastric cancer cells. Among the tested compounds, donor $\mathbf{1}$ and bowls 5-7 showed the strongest anticancer potential in all tested cell types. Moreover, the $\mathrm{IC}_{50}$ of bowl $\mathbf{6}$ in AGS cells was 3.2-fold lower than that of doxorubicin. Cisplatin showed an $\mathrm{IC}_{50}>100 \mu \mathrm{M}$ in AGS cells, indicating that, in comparison with the other tested cell types, gastric cancer cells showed decreased sensitivity to cisplatin (Table 1). Based on these results, we selected the AGS human gastric carcinoma cell line for further analysis of the promising anticancer properties of bowls 5-7. In order to observe the effects of longer treatments, AGS cells were treated with bowl 6 for 24 hours, 48 hours, and 72 hours (Table 2). We found that treatment of bowl $\mathbf{6}$ and cisplatin for 48 hours and 72 hours maintained the anticancer effects, whereas doxorubicin tended to lose its cytotoxic effects on cancer cells.

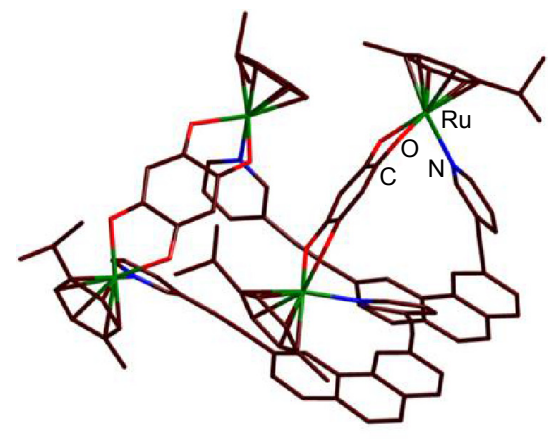

Figure 4 Two views of the X-ray crystal structure of bowl 5 .

Note: The hydrogen atoms and counter anions are omitted for clarity.

\section{Autophagy and apoptosis in bowl 6- treated AGS cells}

To investigate whether the cytotoxic effects of bowl $\mathbf{6}$ in AGS cells were mediated by autophagy or apoptotic cell death, we estimated relative autophagic activity. Green fluorescent protein-transduced cells were stained using the Tali ${ }^{\circledR}$ Viability Kit, while Dead Cell Red was used to stain AGS human gastric cancer cells and COS-7 normal monkey kidney fibroblast cells. Cells were treated with $20 \mu \mathrm{M}$ Bowl 6 for 24 hours, and DAPI or MDC staining was observed under fluorescence microscope. The representative pictures showed that treatment of $20 \mu \mathrm{M}$ Bowl 6 increased MDCstained area compared to control cells, indicating that Bowl 6 stimulated the autophagic vacuoles (Figure 5A). As shown Figure 5B, bowl 6 at concentrations of $5 \mu \mathrm{M}, 10 \mu \mathrm{M}$, and $20 \mu \mathrm{M}$ significantly increased the autophagic activity of AGS cells by $27.1 \%, 48.6 \%$, and $68.4 \%$, respectively, in comparison with the untreated cells. In normal COS-7 cells, bowl 6 at concentrations of $5 \mu \mathrm{M}, 10 \mu \mathrm{M}$, and $20 \mu \mathrm{M}$ significantly increased autophagic activity by $12.5 \%, 18.9 \%$, and $23.3 \%$,

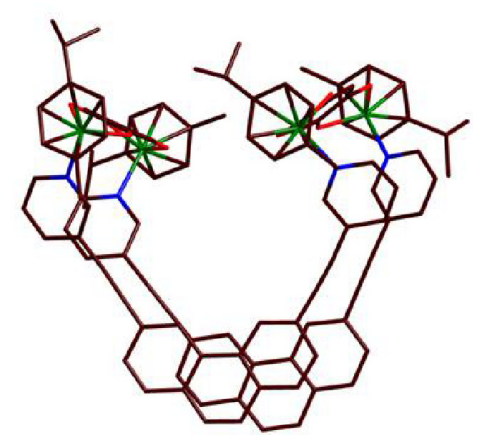


Table I IC 50 values of donor $\mathbf{I}$ and bowls 5-7 against HCT-I5, SK-hep-I, and AGS human cancer cell lines

\begin{tabular}{llll}
\hline Compound & $\mathrm{IC}_{50}(\mu \mathrm{M})$ & & \\
\cline { 2 - 4 } & HCT-I5 & SK-hep-I & AGS \\
\hline $\mathbf{I}$ & $>100$ & $>100$ & $>100$ \\
$\mathbf{5}$ & $>100$ & $>100$ & $>100$ \\
$\mathbf{6}$ & $3.8 \pm 0.15$ & $9.0 \pm 0.18$ & $2.5 \pm 0.34$ \\
$\mathbf{7}$ & $70.1 \pm 1.67$ & $62.9 \pm 2.07$ & $68.6 \pm 1.33$ \\
Cisplatin & $72.4 \pm 9.42$ & $41.1 \pm 5.92$ & $>100$ \\
Doxorubicin & $22.4 \pm 4.88$ & $13.6 \pm 3.02$ & $7.96 \pm 1.40$ \\
\hline
\end{tabular}

Note: Data are presented as mean \pm standard error from at least three independent experiments, as obtained by the 3-[4,5-dimethylthiazol-2-yl]-2,5-diphenyltetrazolium bromide assay using exposure times of 24 hours.

Abbreviation: $\mathrm{IC}_{50}$, the drug concentration necessary for $50 \%$ inhibition of cell viability.

respectively, in comparison with the untreated cells. At a concentration of $20 \mu \mathrm{M}$, bowl 6 significantly increased the autophagic activity of AGS cells by 1.4-fold in comparison with normal cells. As shown Figure 5C, bowl 6 markedly induced concentration-dependent apoptotic cell death in
Table $2 I_{50}$ values of bowl 6 against the AGS human gastric cancer cell lines

\begin{tabular}{llll}
\hline Compound & $\mathrm{IC}_{50}(\mu \mathrm{M})$ & & \\
\cline { 2 - 4 } & $\mathbf{2 4}$ hours & $\mathbf{4 8}$ hours & $\mathbf{7 2}$ hours \\
\hline $\mathbf{6}$ & $2.7 \pm 0.11$ & $2.3 \pm 0.08$ & $2.2 \pm 0.08$ \\
Cisplatin & $76.2 \pm 2.36$ & $31.5 \pm 4.03$ & $9.3 \pm 0.32$ \\
Doxorubicin & $6.3 \pm 0.13$ & $5.8 \pm 0.09$ & $18.6 \pm 1.28$ \\
\hline
\end{tabular}

Note: Data are presented as mean \pm standard error from at least three independent experiments, as obtained by the 3-[4,5-dimethylthiazol-2-yl]-2,5-diphenyltetrazolium bromide assay using exposure times of 24 hours, 48 hours, and 72 hours.

Abbreviation: $\mathrm{IC}_{50}$, the drug concentration necessary for $50 \%$ inhibition of cell viability.

AGS cells, while normal COS-7 cells were less susceptible to bowl $\mathbf{6}$ and had a higher ratio of live cells than the AGS cells following treatment with the same concentration of bowl 6. These results suggest that bowl 6 is selectively cytotoxic to cancer cells via induction of autophagic activity and apoptotic cell death, while producing no significant changes in autophagy or apoptosis in normal fibroblasts.

\section{A}
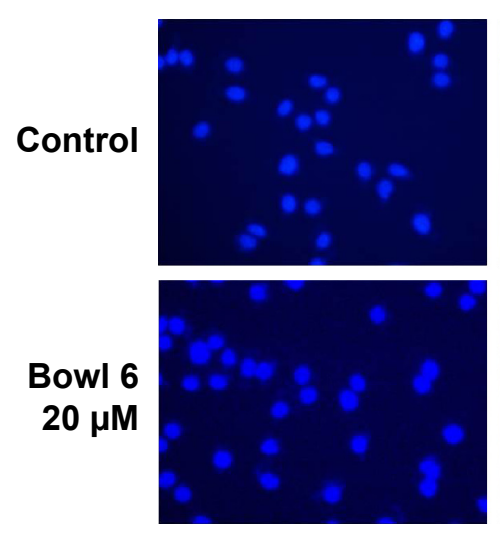

\section{B}

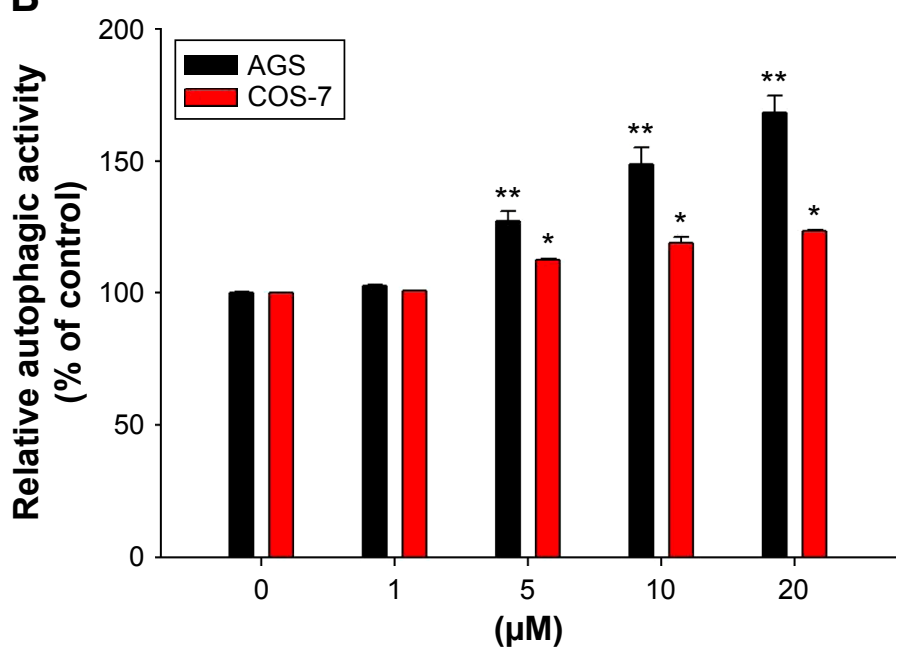

Autophagic vacuoles
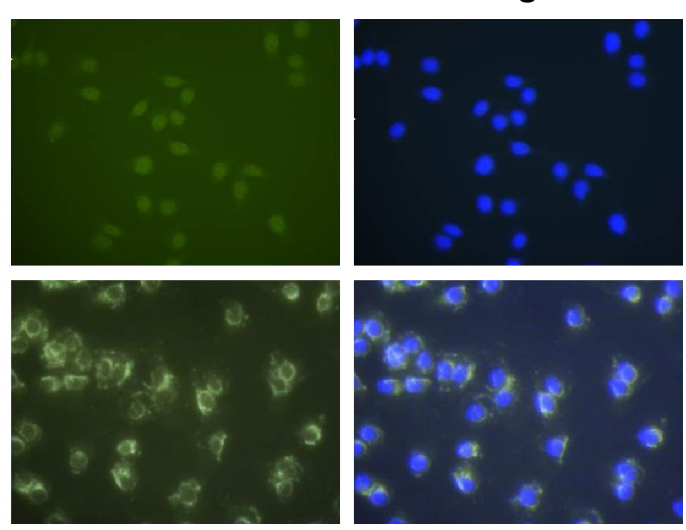

Figure 5 (Continued) 

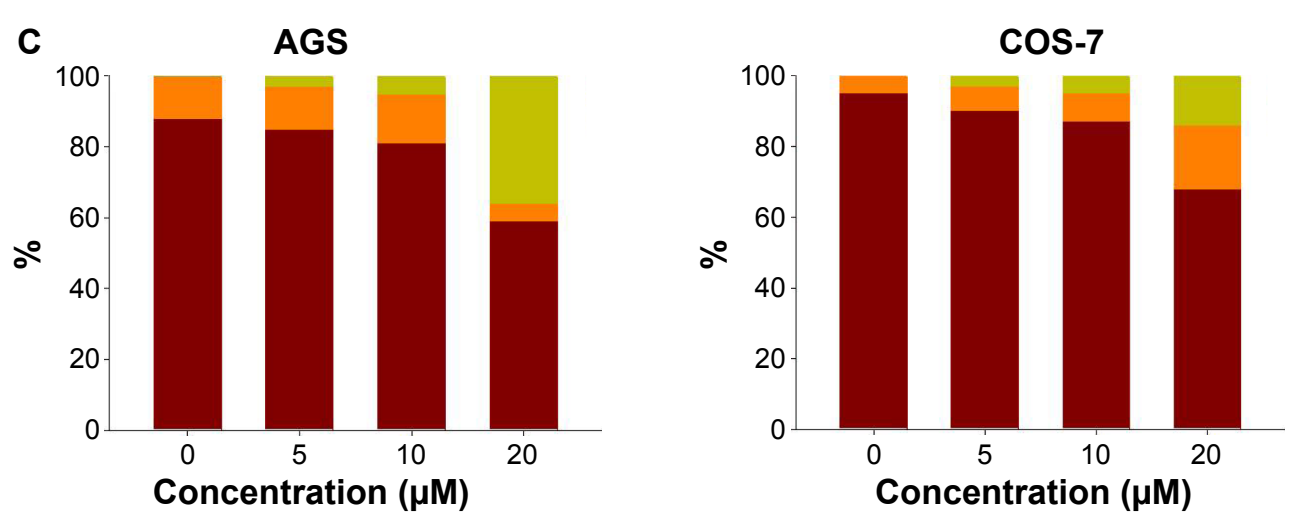

Live Necrosis Apoptosis

Figure 5 Effects of bowl $\mathbf{6}$ on programmed cell death.

Notes: (A) The representative pictures of MDC, DAPI-stained cells with merged pictures in AGS cells. Cells were treated with $20 \mu \mathrm{M}$ bowl 6 for 24 hours and DAPI or MDC staining was observed under fluorescence microscope. (B) Relative autophagic activity following exposure to bowl 6 in the AGS and COS-7 cell lines. The cells were treated with the samples for 24 hours. (C) Analysis of apoptotic cell death in the AGS and COS-7 cell lines. Live cells and apoptotic cells were stained red and green. Apoptosis was assessed using a Tali ${ }^{\circledR}$ Image-Based Cytometer (Thermo Fisher Scientific). The results are mean \pm standard error of mean (SEM) of triplicates from a representative experiment. ${ }^{*} P<0.05,{ }^{*} * P<0.01$ compared to 0 .

Abbreviation: MDC, monodansylcadaverine.

\section{Effects of autophagy and apoptosis induced by bowl 6 in AGS cells}

We examined the cellular mechanisms through which bowl 6 activated autophagy in AGS cells by measuring the expression of p62, a selective target of autophagy, and the intracellular distribution of LC3 protein, a reliable autophagosome marker, using Western blotting. p62 protein is a commonly used marker for the estimation of autophagic flux that binds to LC3 and is degraded during autophagy, leading to accumulation of p62 when autophagy is inhibited. ${ }^{12}$ LC3 plays a key role in the formation of autophagosomes and has been identified in two forms, a cytosolic form designated LC3-I and a membrane-bound form designated LC3-II. ${ }^{41}$ Increased conversion of LC3, in particular of LC3-I to LC3-II, is observed during autophagy. Bowl 6 significantly upregulated the expression of p62 protein and enhanced LC3-I to LC3-II conversion in the AGS cells in comparison with the untreated cells (Figure 6A).

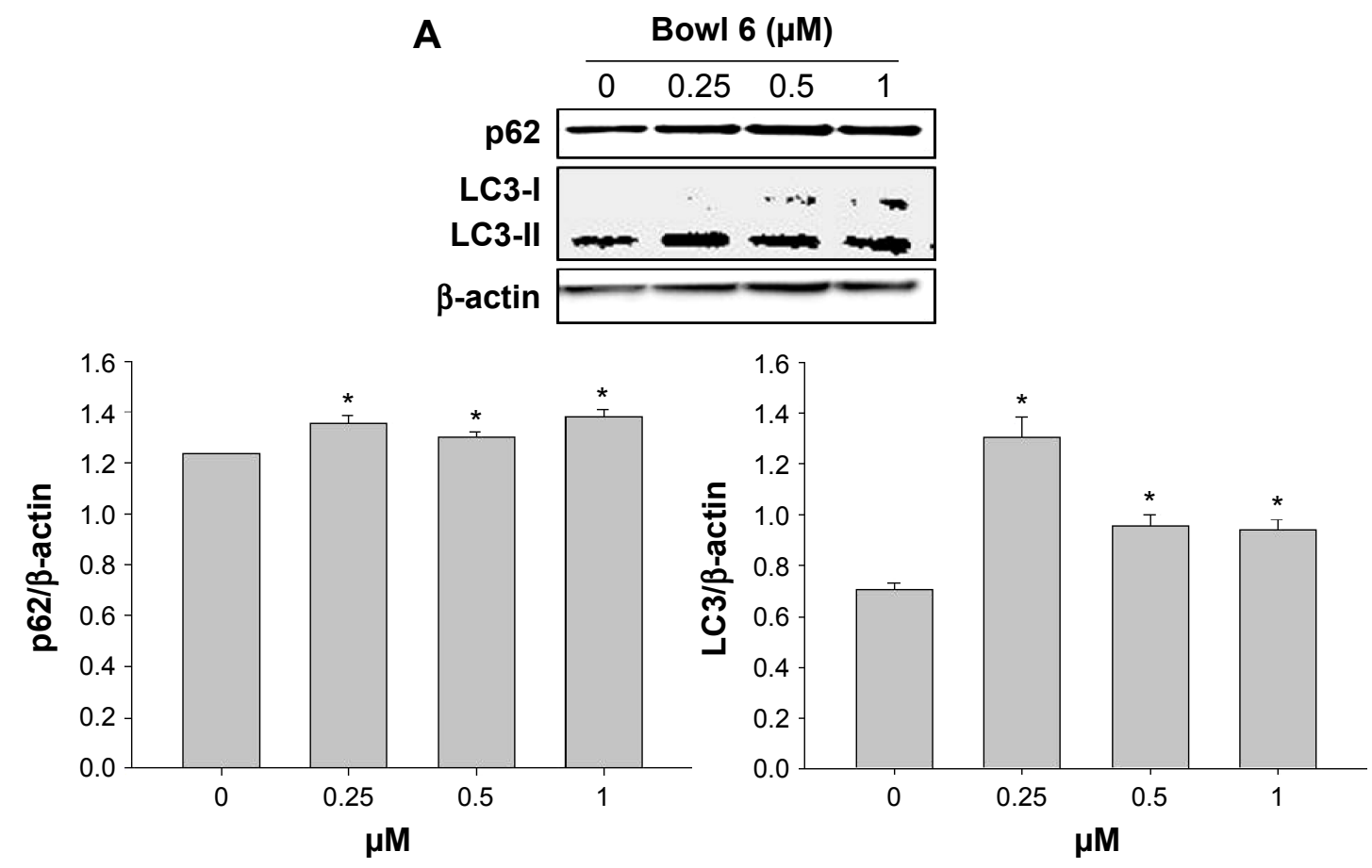

Figure 6 (Continued) 
B
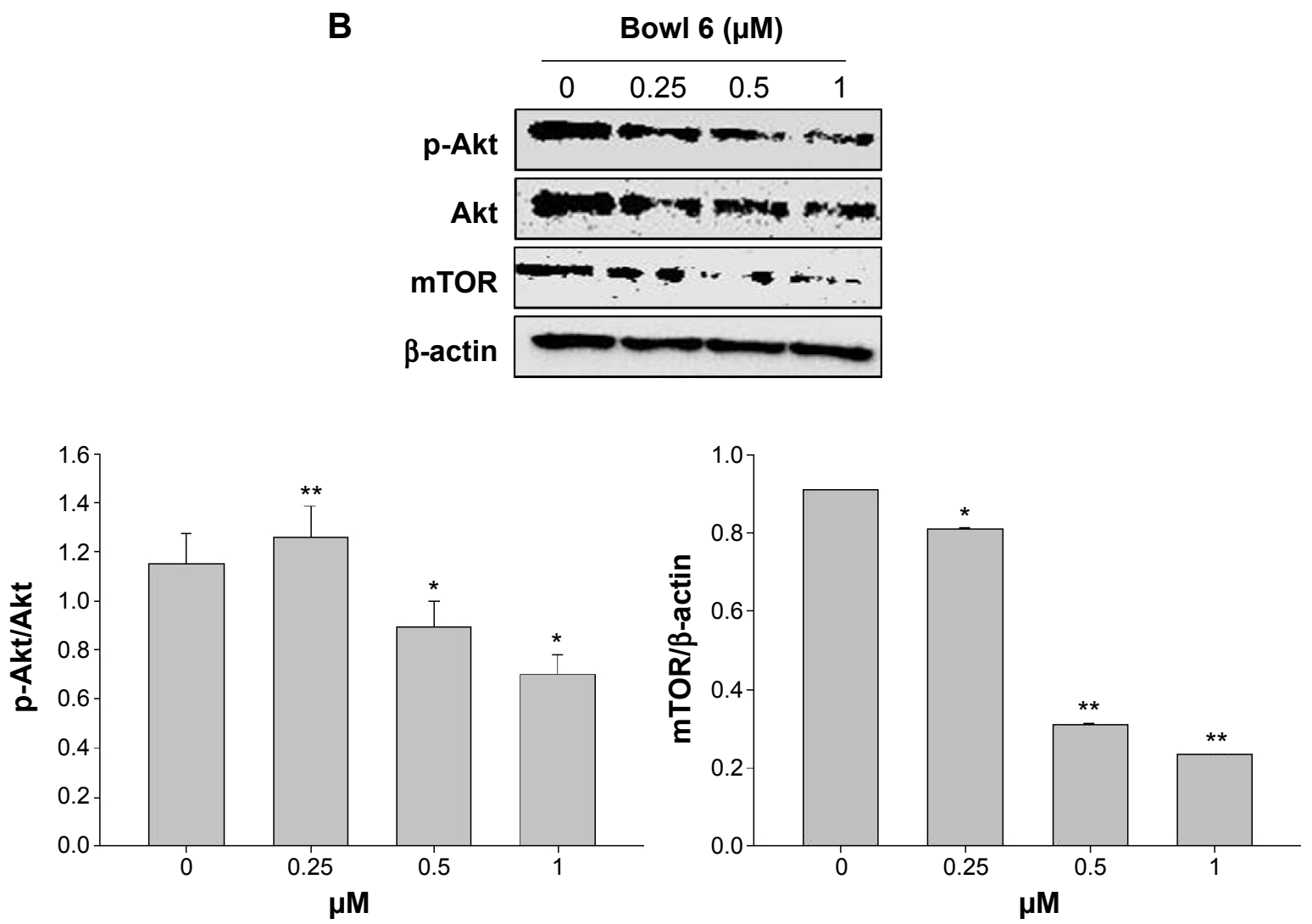

Figure 6 Regulation of programmed cell death by bowl 6.

Notes: (A) LC3 and p62 protein levels indicated that bowl 6 induced an autophagic response. AGS and COS-7 cells were treated with bowl 6 at a concentration of $0-1 \mu$ M for 24 hours for the autophagic inducible protein assay. (B) Apoptotic and autophagic effects of bowl 6 on Akt and upstream expression in the AGS and COS-7 cell lines. Cells were treated with bowl 6 at a concentration of 0-20 $\mu \mathrm{M}$ for 24 hours for the Akt/mTOR Western blot analysis. Bar graphs of p62, LC3 and mTOR protein densitometry normalized by $\beta$-actin concentrations, and $\mathrm{p}$-AKT was normalized by AKT. The results are mean \pm standard error of mean (SEM) of triplicates from a representative experiment. $* P<0.05$, $* * P<0.01$ compared to 0 .

Abbreviations: LC3, light chain 3; mTOR, mammalian target of rapamycin.

To further elucidate the mechanisms underlying bowl 6-induced apoptosis in AGS cells, we assessed phosphorylation of Akt and mTOR proteins by Western blotting. In human cancers, activation of the Akt/mTOR pathway via phosphorylation leads to cancer cell proliferation and metastasis, while stimulating autophagy. Because inhibition of the Akt/ mTOR pathway is associated with inhibition of autophagy in cancer cells, potential anticancer agents can maintain tumor survival or induce tumor growth. ${ }^{12,41-43}$ Expression of p-Akt in the bowl 6-treated AGS cells significantly decreased in comparison with that in the untreated cells, which was in accordance with the downregulation of mTOR in comparison with the untreated cells (Figure 6B). To assess whether bowl 6 induced caspase-mediated apoptosis, caspase-3 activity was measured using a substrate cleavage-based assay. As shown Figure 7, bowl 6 significantly increased caspase-3 activity in a dose-dependent manner in comparison with that of the untreated cells. These results imply that bowl 6 induced cancer cell death by inhibiting the Akt/mTOR pathway, followed by activation of autophagy.

\section{Stability of bowl 6 in DMSO and cell culture medium}

The stability of bowl 6 was examined in DMSO and culture medium (10\% fetal bovine serum in Dulbecco's Modified

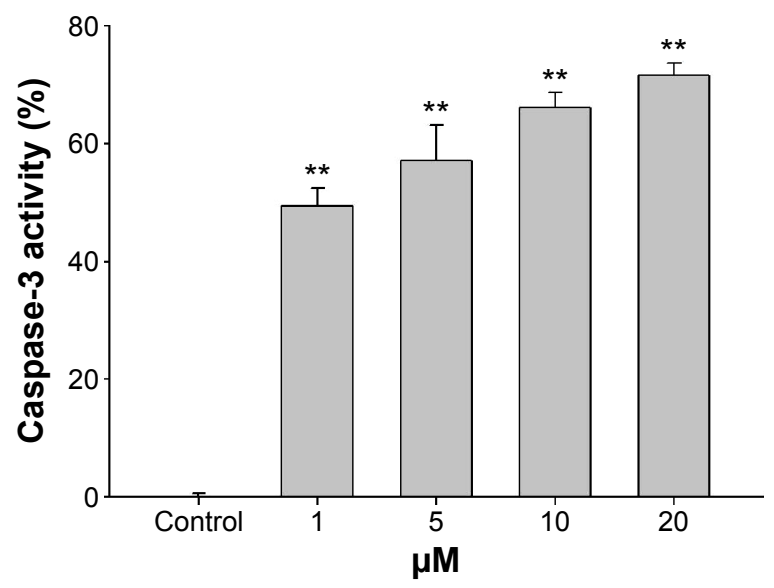

Figure 7 Caspase-3 activity in AGS cells following treatment with bowl 6. Note: Caspase-3 activity was evaluated by a luminescence assay. The results are mean \pm standard error of mean (SEM) of triplicates from a representative experiment. $* * P<0.01$ compared to control. 


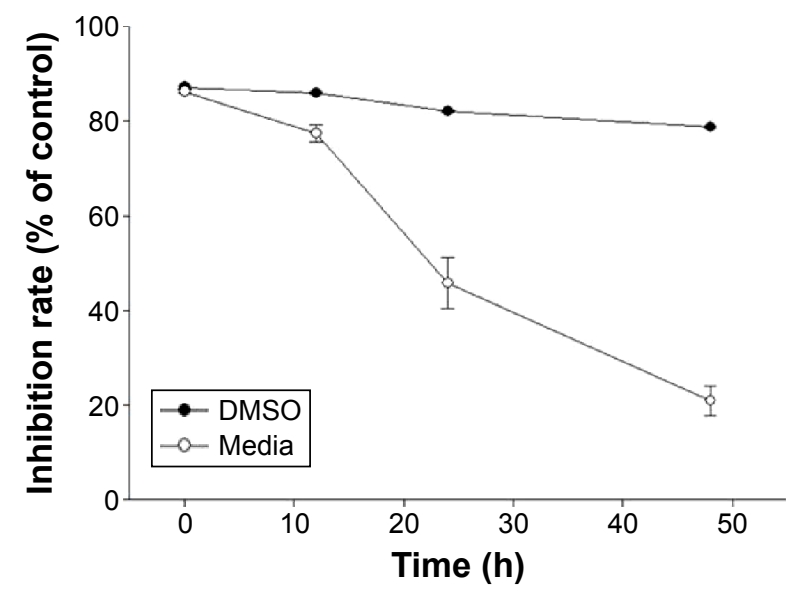

Figure 8 Loss of the growth-inhibitory activity of bowl 6 following preincubation in AGS cell culture medium.

Note: DMSO was used as a control.

Abbreviations: DMSO, dimethyl sulfoxide; h, hours.

Eagle's Medium), using conditions similar to those under which the drug is likely to be handled during the course of biological studies. Bowl $6(10 \mu \mathrm{M})$ was preincubated in the culture medium at $37^{\circ} \mathrm{C}$ for various periods of time before it was added to the AGS cell culture. As a control experiment, bowl 6 was preincubated in DMSO at $37^{\circ} \mathrm{C}$ for the same periods of time. As shown in Figure 8, bowl 6 was stable in DMSO for 50 hours at a concentration of $10 \mu \mathrm{M}$. After preincubation in the culture medium for 24 hours, the inhibitory rate of bowl 6 decreased by $50 \%$.

\section{Conclusion}

In this study, we report the synthesis of three new $\sim 2$-nmr-sized tetranuclear molecular bowls by coordination-driven self-assembly of a phenanthrene-derived donor and $\mathrm{Ru}$ (II) $p$-cymene acceptors. Formation of metalla-rectangles was established by various spectroscopic techniques. The molecular structure of one of the molecular bowls was confirmed by single-crystal $\mathrm{X}$-ray diffraction analysis. Bowl $\mathbf{6}$ produced cytotoxicity in AGS human gastric carcinoma cells by inducing autophagy via activation of the Akt/mTOR pathway. We propose that bowl 6 selectively induces autophagic and apoptotic PCD in cell lines derived from gastric cancer cells and may thus be a viable candidate drug for the treatment of gastric cancer. This study was the first set of in vitro observations regarding the antitumor effects of nano-sized $\mathrm{Ru}(\mathrm{II})$-based, self-assembled architectures through induction of apoptosis and autophagy in human cancer cells. Future research should confirm the anticancer effects of self-assembled molecular bowls in vivo and study pharmaceutical kinetics of orally administrated self-assembled molecular bowls.

\section{Acknowledgments}

This study was supported by the Basic Science Research program through the National Research Foundation of Korea (NRF) funded by the Ministry of Science, ICT and Future Planning (NRF-20013R1A1A2006859) as well as by the Ministry of Education (NRF-2014R1A1A2007828) Priority Research Centers program (2009-0093818). X-ray diffraction experiments using synchrotron radiation were performed at the Pohang Accelerator Laboratory in Korea. HK also would like to thank the Research and Development Program of KIER (B5-2513).

\section{Disclosure}

The authors report no conflicts of interest in this work.

\section{References}

1. Clarke MJ. Ruthenium metallopharmaceuticals. Coord Chem Rev. 2003; 236:209-233.

2. Clarke MJ, Zhu F, Frasca DR. Non-platinum chemotherapeutic metallopharmaceuticals. Chem Rev. 1999;99:2511-2534.

3. Levina A, Mitra A, Lay PA. Recent developments in ruthenium anticancer drugs. Metallomics. 2009;1:458-470.

4. Allardyce CS, Dyson PJ. Ruthenium in medicine: current clinical uses and future prospects. Platin Met Rev. 2001;45:62-69.

5. Clarke MJ. Oncological implication of the chemistry of ruthenium. Met Ions Biol Syst. 1980;11:231-283.

6. Dyson PJ, Sava G. Metal-based antitumour drugs in the post genomic era. Dalton Trans. 2006;16:1929-1933.

7. Cook TR, Stang PJ. Recent developments in the preparation and chemistry of metallacycles and metallacages via coordination. Chem Rev. 2015:doi: 10.1021/cr5005666.

8. Cook TR, Vajpayee V, Lee MH, Stang PJ, Chi KW. Biomedical and biochemical applications of self-assembled metallacycles and metallacages. Acc Chem Res. 2013;46:2464-2474.

9. Mishra A, Kang SC, Chi KW. Coordination-driven self-assembly of areneruthenium compounds. Eur J Inorg Chem. 2013;2013:5222-5232.

10. Therrien B, Süss-Fink G, Govindaswamy P, Renfrew AK, Dyson PJ. The "complex-in-a-complex" cations [(acac)2M subset Ru6(p-iprc6H4 Me6(tpt)2(dhbq)3]6+: a Trojan horse for cancer cells. Angew Chem Int Ed Engl. 2008;47:3773-3776.

11. Zava O, Mattsson J, Dyson PJ, Therrien B. Evidence for drug release from a metalla-cage delivery vector following cellular internalization. Chem Eur J. 2010;16:1428-1431.

12. Dubey A, Min JW, Koo HJ, et al. Anticancer potency and multidrugresistant studies of self-assembled arene-ruthenium metallarectangles. Chem Eur J. 2013;19:11622-11628.

13. Mishra A, Jeong YJ, Jo JH, Kang SC, Lah MS, Chi KW. Anticancer potency studies of coordination driven self assembled arene-Ru-based metalla-bowls. Chem Biol Chem. 2014;15:695-700.

14. Mishra A, Jeong YJ, Jo JH, Kang SC, Kim H, Chi KW. Coordinationdriven self-assembly and anticancer potency studies of arene-rutheniumbased molecular metalla-rectangles. Organometallics. 2014;33: 1144-1151.

15. Therrien B. Biologically relevant arene ruthenium metalla-assemblies. Cryst Eng Comm. 2015;17:484-491.

16. Han YF, Jia WG, Yu WB, Jin GX. Stepwise formation of organometallic macrocycles, prisms and boxes from $\mathrm{Ir}, \mathrm{Rh}$ and $\mathrm{Ru}$-based half-sandwich units. Chem Soc Rev. 2009;38:3419-3434.

17. Lee HW, Elumalai P, Singh N, Kim H, Lee SU, Chi KW. Selective synthesis of ruthenium (II) metalla[2]catenane via solvent and guestdependent self-assembly. J Am Chem Soc. 2015;137:4674-4677. 
18. Singh N, Jo JH, Song YH, et al. Coordination-driven self-assembly of an iridium-cornered prismatic cage and encapsulation of three heteroguests in its large cavity. Chem Commun. 2015;51:4492-4495.

19. Vock CA, Ang WH, Scolaro C, et al. Development of ruthenium antitumor drugs that overcome multidrug resistance mechanisms. $J$ Med Chem. 2007;50:2166-2175.

20. Kovács A, Vasas A, Hohmann J. Natural phenanthrenes and their biological activity. Phytochemistry. 2008;69:1084-1110.

21. Qian CD, Jiang FS, Yu HS, et al. Antibacterial biphenanthrenes from the fibrous roots of Bletilla striata. J Nat Prod. 2015;78(4):939-943.

22. Ding DJ, Cao XY, Dai F, et al. Synthesis and antioxidant activity of hydroxylated phenanthrenes as cis-restricted resveratrol analogues. Food Chem. 2012;135:1011-1019.

23. Chen CY, Yang SC, Lee KH, et al. The antitumor agent PBT-1 directly targets HSP90 and hnRNP A2/B1 and inhibits lung adenocarcinoma growth and metastasis. J Med Chem. 2014;57:677-685.

24. Saraswati S, Kanaujia PK, Kumar S, Kumar R, Alhaider AA. Tylophorine, a phenanthraindolizidine alkaloid isolated from Tylophora indica exerts antiangiogenic and antitumor activity by targeting vascular endothelial growth factor receptor 2-mediated angiogenesis. Mol Cancer. 2013;12:82-97.

25. Williams D, Norman G, Khoury C, et al. Evidence for a second messenger function of dUTP during Bax mediated apoptosis of yeast and mammalian cells. Biochim Biophys Acta. 2011;1813(2):315-321.

26. Gozuacik D, Kimchi A. Autophagy and cell death. Curr Top Dev Biol. 2007;78:217-245.

27. Law BY, Chan WK, Xu SW, et al. Natural small-molecule enhancers of autophagy induce autophagic cell death in apoptosis-defective cells. Sci Rep. 2014;4:5510.

28. Denton D, Nicolson S, Kumar S. Cell death by autophagy: facts and apparent artefacts. Cell Death Differ. 2012;19(1):87-95.

29. Choi KS. Autophagy and cancer. Exp Mol Med. 2012;44(2):109-120.

30. Levine B, Mizushima N, Virgin HW. Autophagy in immunity and inflammation. Nature. 2011;469(7330):323-335.

31. He C, Bassik MC, Moresi V, et al. Exercise-induced BCL2-regulated autophagy is required for muscle glucose homeostasis. Nature. 2012; 481(7382):511-515.

32. Williams A, Sarkar S, Cuddon P, et al. Novel targets for Huntington's disease in an mTOR-independent autophagy pathway. Nat Chem Biol. 2008; 4(5):295-305.
33. Rabinowitz JD, White E. Autophagy and metabolism. Science. 2010; 330(6009):1344-1348

34. Li X, Xu HL, Liu YX, An N, Zhao S, Bao JK. Autophagy modulation as a target for anticancer drug discovery. Acta Pharmacol Sin. 2013;34(5): 612-624.

35. Fimia GM, Piacentini M. Regulation of autophagy in mammals and its interplay with apoptosis. Cell Mol Life Sci. 2010;67:1581-1588.

36. Pan WR, Chen PW, Chen YL, Hsu HC, Lin CC, Chen WJ. Bovine lactoferricin B induces apoptosis of human gastric cancer cell line AGS by inhibition of autophagy at a late stage. J Dairy Sci. 2013;96(12): 7511-7520.

37. Barry NPE, Furrer J, Therrien B. In-and out-of-cavity interactions by modulating the size of ruthenium metallarectangles. Helv Chim Acta. 2010; 93:1313-1328.

38. Nakamura Y, Tsuihiji T, Mita T, et al. Synthesis, structure, and electronic properties of syn-[2.2]phenanthrenophanes: first observation of their excimer fluorescence at high temperature. J Am Chem Soc. 1996;118: 1006-1012.

39. Remple K, Stone L. Assessment of GFP expression and viability using the Tali image-based cytometer. J Vis Exp. 2011;17(57):3659.

40. Bjørkøy G, Lamark T, Brech A, et al. p62/SQSTM1 forms protein aggregates degraded by autophagy and has a protective effect on huntingtin-induced cell death. J Cell Biol. 2005;171(4):603-614.

41. Kabeya Y, Mizushima N, Ueno T, et al. LC3, a mammalian homologue of yeast Apg8p, is localized in autophagosome membranes after processing. EMBO J. 2000;19(21):5720-5728.

42. Kim A, Yim NH, Ma JY. Samsoeum, a traditional herbal medicine, elicits apoptotic and autophagic cell death by inhibiting Akt/mTOR and activating the JNK pathway in cancer cells. BMC Complement Altern Med. 2013;13:233-246.

43. Poornima P, Weng CF, Padma VV. Neferine from Nelumbo nucifera induces autophagy through the inhibition of PI3K/Akt/mTOR pathway and ROS hyper generation in A549 cells. Food Chem. 2013;41(4): 3598-3605.

44. Chen Z, Yang L, Liu Y, et al. LY294002 and rapamycin promote coxsackievirus-induced cytopathic effect and apoptosis via inhibition of PI3K/AKT/mTOR signaling pathway. Mol Cell Biochem. 2014; 385(1-2):169-177.
International Journal of Nanomedicine

\section{Publish your work in this journal}

The International Journal of Nanomedicine is an international, peerreviewed journal focusing on the application of nanotechnology in diagnostics, therapeutics, and drug delivery systems throughout the biomedical field. This journal is indexed on PubMed Central, MedLine, CAS, SciSearch $®$, Current Contents $\AA /$ Clinical Medicine,

\section{Dovepress}

Journal Citation Reports/Science Edition, EMBase, Scopus and the Elsevier Bibliographic databases. The manuscript management system is completely online and includes a very quick and fair peer-review system, which is all easy to use. Visit http://www.dovepress.com/ testimonials.php to read real quotes from published authors. 